\title{
Seasonal changes of melatonin secretion in relation to the reproductive cycle in sheep
}

\section{T. Misztal, Katarzyna Romanowicz and B. Barcikowski}

\author{
The Kielanowski Institute of Animal Physiology and Nutrition, \\ Polish Academy of Sciences \\ 05-110 Jablonna, Poland
}

(Received 20 November 1995; accepted 12 January 1996)

\begin{abstract}
The seasonal changes in circulating melatonin were determined in ewes and rams exposed to the natural photoperiod at $52^{\circ} \mathrm{N}$ during first year and in rams under the artificial daylength conditions (16D:8L), during the second year of the experiment. The changes in the luteotropin (LH) and testosterone ( $\mathrm{T}$ ) concentrations in blood plasma of rams were also monitored.

The mean daily concentrations of plasma melatonin in the ewes varied through a year from $41 \pm 7$ to $112 \pm 13 \mathrm{pg} / \mathrm{ml}$ and a significant increase above the daily values occured during the first hour after sunset. The duration of nightly melatonin secretion was longer during the period of short day (10-12h), than under the long day conditions $(8-10 \mathrm{~h})$. The mean nightly concentrations of circulating melatonin were highest from August to February: $171 \pm 73$ to $329 \pm 187 \mathrm{pg} / \mathrm{ml}$ for individual ewes.

The mean concentrations of LH and testosterone in blood plasma of rams, under the natural photoperiod, were low during the period of sexual quiescence and the significantly high levels occured in August: $6.2 \pm 0.4 \mathrm{ng} / \mathrm{ml}$ and in October: $4.6 \pm 0.7 \mathrm{ng} / \mathrm{ml}$, respectively. Shortening of daylength from 16 to $8 \mathrm{~h}$ in May evoked in rams an increase in duration of melatonin secretion from 6 to $14 \mathrm{~h}$. This advanced reproductive function by 6 to 9 weeks, with the peak of $\mathrm{LH}$ and testosterone secretion noted at the beginning of July: $8.2 \pm 0.9 \mathrm{ng} / \mathrm{ml}$ and in August: $5.2 \pm 0.9 \mathrm{ng} / \mathrm{ml}$, respectively. Nevertheless the duration of reproductive activity of rams during the second year of the experiment was shorter than under the natural photoperiodic conditions.
\end{abstract}

KEY WORDS: seasonal rhythms, melatonin, LH, testosterone

\section{INTRODUCTION}

Sheep are „short-day breeders". Changes in their reproductive function are associated with changes in the secretion of gonadotropins from the anterior pituitary gland (Lincoln et al., 1977; Karsch et al., 1984), which are primarily 
regulated by the release of gonadotropin-releasing hormone (GnRH) from the hypothalamus (Clark and Cummins, 1982; Barrell et al., 1992). The mechanism whereby photoperiod affects the hypothalamic-pituitary axis is poorly understood. There is evidence, that photoperiodic information is transduced to the reproductive neuroendocrine axis of the ewe by the pineal gland via the circadian rhythm of melatonin secretion (Bittman et al. $1983 \mathrm{a}, \mathrm{b}$ ). This rhythm, generated in the suprachiasmatic nucleus (Moore and Klain, 1974), is characterized by low levels of secretion during the day and high levels at night. The duration of melatonin secretion in sheep depends on the length of the night and variations in the circulating patterns of melatonin constitute an endocrine code for daylength (Rollag et al., 1978; Bittman et al., 1983a; Wayne et al.,1988). A large number of studies have shown advances of the breeding season in sheep by artificially altering daylength (Ducker et al., 1970) and by timed administration of exogenous melatonin (Nett and Niswender, 1982; Arendt et al. 1983; Bittman and Karsch, 1984), which mimic the onset of short photoperiodic conditions. Two mechanisms involving melatonin were postulated to account for the long-term changes in reproductive activity in sheep. The first, relating to a change in the generation of the melatonin rhythm was suggested by Almeida and Lincoln (1984), who demonstrated high levels of melatonin secretion during the day in photorefractory rams. On the other hand, there is evidence, that refractoriness to both inhibitory and stimulatory daylengths results from a change in the processing of the melatonin signal, not in a change in its secretory pattern (Karsch et al.,1986; Malpaux et al., 1987, 1988b). In view of the fact that transition from anoestrus to the breeding season in sheep maintained in the natural photoperiodic conditions can occur in the absence of a decrease in daylength as an endogenously generated process (Robinson and Karsch, 1988; Karsch et al.,1989), it motivated our considerations for investigating the modulatory role of melatonin in this process. Our studies were therefore conducted to investigate the twenty-four hour and annual rhythms of melatonin secretion in ewes, in relation to changes in the reproductive activity under the natural photoperiod. Simultaneously in rams, the effects of natural and artificial daylength conditions on the melatonin, $\mathrm{LH}$ and testosterone secretion were monitored.

\section{MATERIAL AND METHODS}

\section{Animals and Treatment}

Eight sexually mature sheep ( 4 ewes and 4 rams), local type of the Polish Lowland breed were used in the experiment. They were maintained indoors, in 

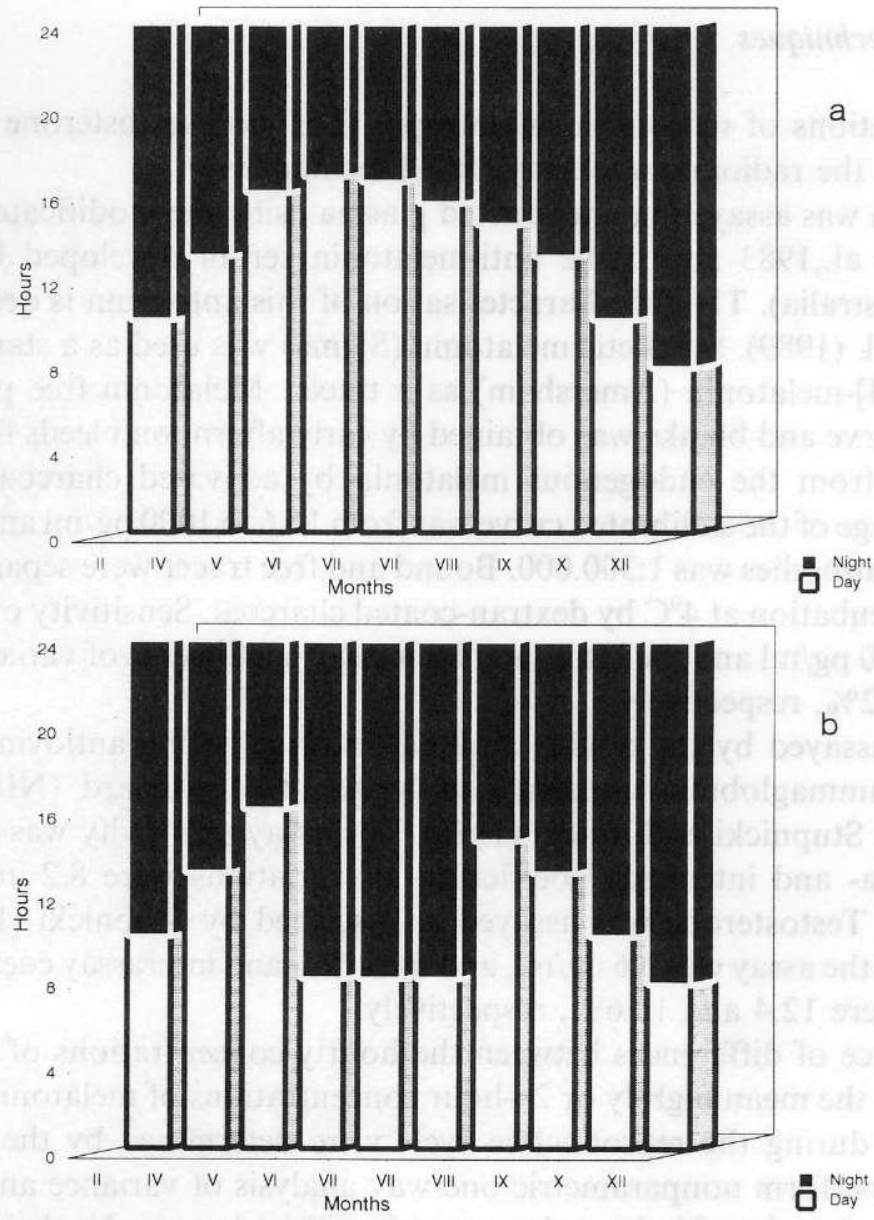

Figure 1. Natural (a) and artificial (b) daylength regimes during both years of the experiment

individual cages and fed a constant diet of commercial concentrates, with hay and water available ad libitum. The studies were carried out during two years, from February 1991 to January 1993. In the first year, ewes and rams were affected by influence of the natural photoperiod at the $52^{\circ} \mathrm{N}$. In the second year, daylength for the rams was reduced from 16 to 8 hours for a period of 9 weeks beginning 25 May. The dark phase was from $3 \mathrm{pm}$ to $7 \mathrm{am}$. Blood samples were collected at hourly intervals, from an indwelling jugular vein catheter for 24 hours on ten days of the year (Figures 1a and 1b). After centrifugation in heparinized tubes, blood plasma was stored at $-20^{\circ} \mathrm{C}$ until assayed for hormones. 
Analytical Techniques

Concentrations of melatonin, luteotropin (LH) and testosterone (T), were measured by the radioimmunoassay (RIA) techniques.

Melatonin was assayed in unextracted plasma using the modificated method of Fraser et al.,1983 and ovine anti-melatonin serum developed by Foldes (CSIRO, Australia). The full characterisation of this antiserum is described by Maxwell et al. (1989). Synthetic melatonin (Sigma) was used as a standard and [O-methyl- ${ }^{3} \mathrm{H}$ ]-melatonin (Amersham) as a tracer. Melatonin free plasma for calibrated curve and blanks was obtained by early afternoon bleeds from sheep and striped from the endogenous melatonin by activated charcoal Norit-A (Sigma). Range of the callibrated curve was from 15.6 to $1000 \mathrm{pg} / \mathrm{ml}$ and working dilution of antibodies was 1:300.000. Bound and free tracer were separated after overnight incubation at $4^{\circ} \mathrm{C}$ by dextran-coated charcoal. Sensitivity of the assay was $16.8 \pm 8.0 \mathrm{pg} / \mathrm{ml}$ and the intra- and interassay coefficients of variations were 10.5 and $13.2 \%$, respectively.

LH was assayed by the double-antibody method, using antiovine-LH and antirabbit-gammaglobulin antisera and bovine LH standard (NIH-LH-B6) according to Stupnicki and Madej (1976). The assay sensitivity was $0.3 \mathrm{ng} / \mathrm{ml}$, and the intra- and interassay coefficients of variations were 8.2 and $12.5 \%$, respectively. Testosterone was assayed as discribed by Stupnicki (1985). The sensitivity of the assay was $0.6 \mathrm{ng} / \mathrm{ml}$, and the intra- and interassay coefficients of variations were 12.4 and $14.6 \%$, respectively.

Significance of differences between the hourly concentrations of melatonin and between the mean nightly or 24-hour concentrations of melatonin, $\mathrm{LH}$ and testosterone during the reproductive cycle were determined by the computer program to perform nonparametric one-way analysis of variance and multiple comparison of ranks of independent samples (Theodorsson-Norheim, 1986).

\section{RESULTS}

\section{Melatonin}

There were clear day-night rhythms in circulating plasma melatonin in ewes and rams housed under the natural photoperiodic conditions with significantly $(\mathrm{P} \leqslant 0.01 ; \mathrm{P} \leqslant 0.001)$ higher concentrations occuring always during hours of darkness. The twenty-four hour profiles of mclatonin secretion in ewes and in rams during four various months of a year are shown in Figures 2 and 3, respectively. The mean daily concentrations of plasma melatonin in ewes varied through a year from $41 \pm 7 \mathrm{pg} / \mathrm{ml}$ on the beginning of July to $112 \pm 13 \mathrm{pg} / \mathrm{ml}$ in 


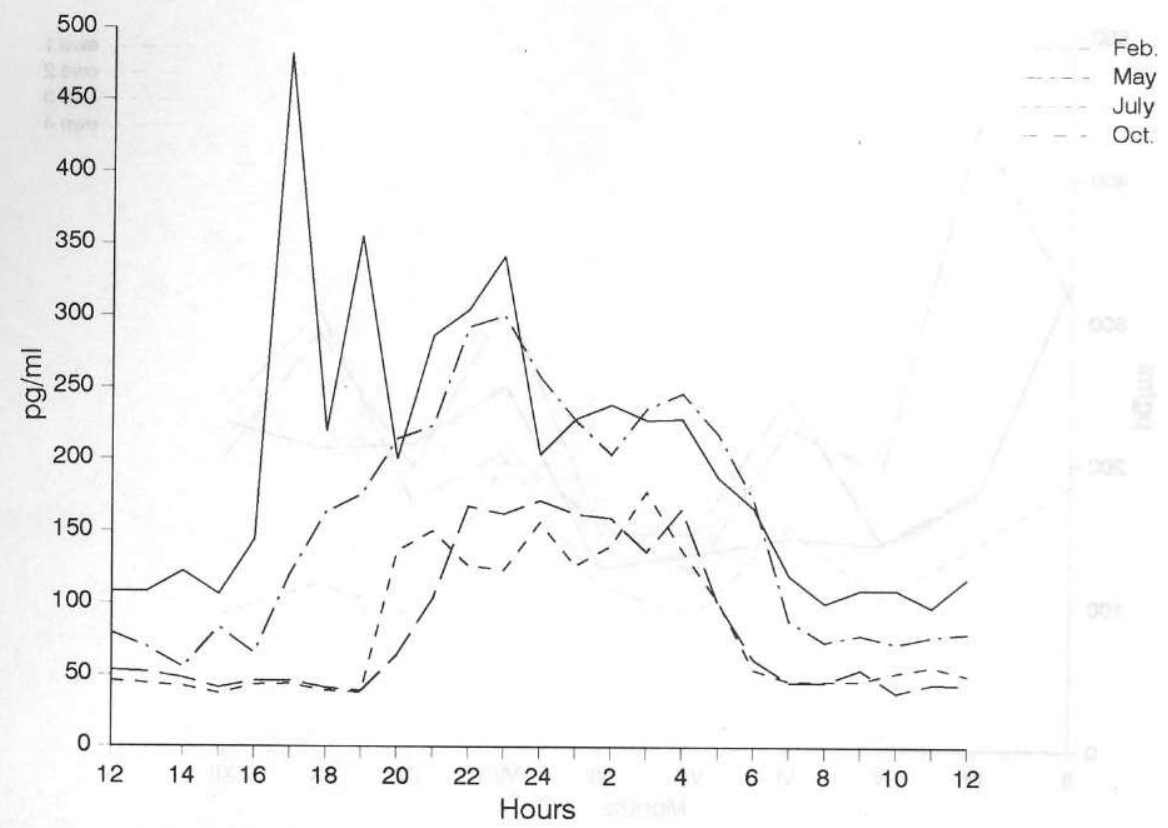

Figure 2. Mean 24 h patterns of melatonin secretion at four times of the year in ewes $(n=4)$ kept under the natural photoperiod at $52^{\circ} \mathrm{N}$

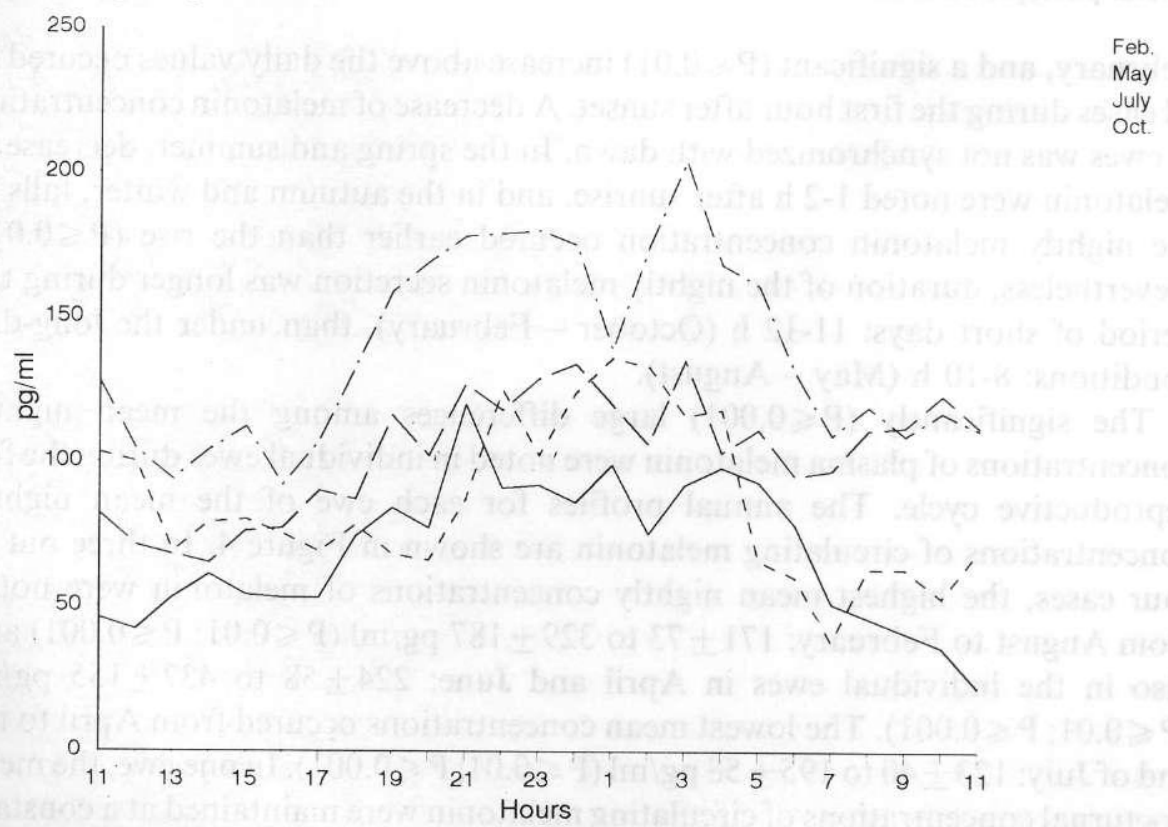

Figure 3. Mean $24 \mathrm{~h}$ patterns of melatonin secretion at four times of the year in rams $(n=4)$ kept under the natural photoperiod at $52^{\circ} \mathrm{N}$ 


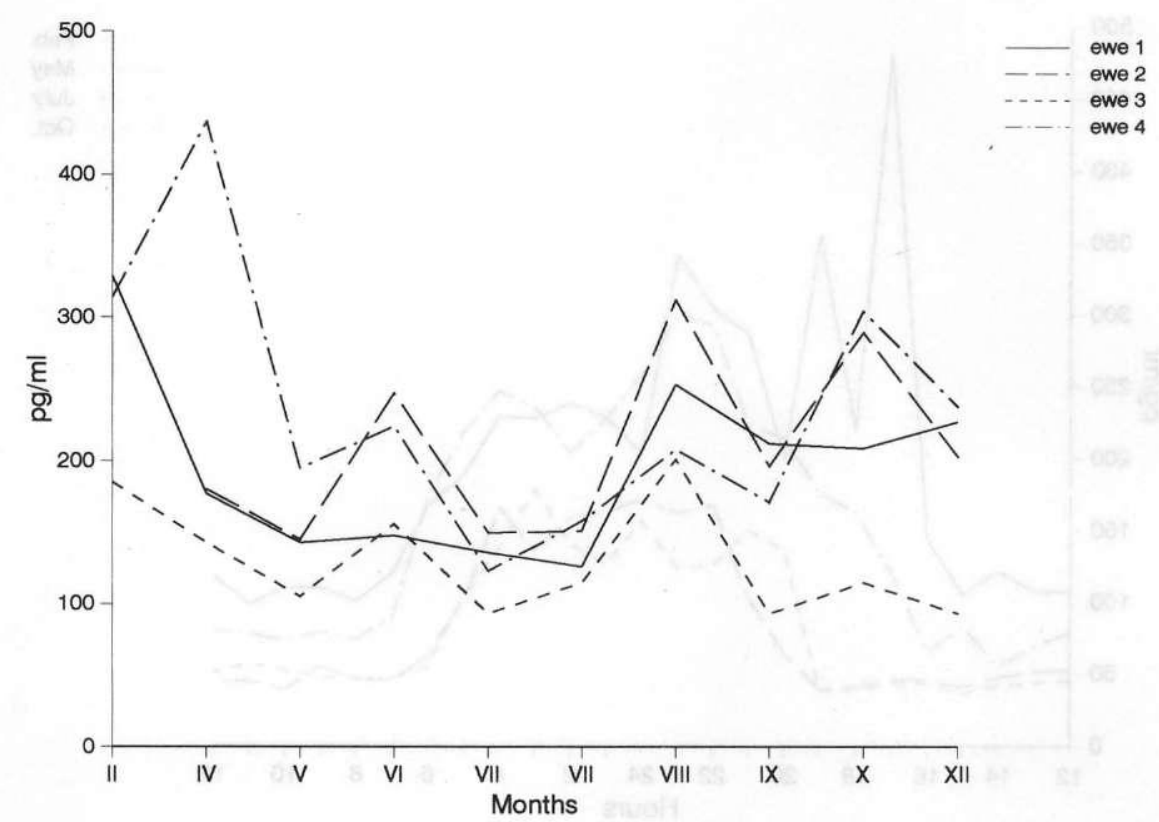

Figure 4. Annual patterns of the mean nightly melatonin concentrations in ewes kept under the natural photoperiod at $52^{\circ} \mathrm{N}$

February, and a significant $(\mathrm{P} \leqslant 0.01)$ increase above the daily values occured in all cases during the first hour after sunset. A decrease of melatonin concentration in ewes was not synchronized with dawn. In the spring and summer, decrease in melatonin were noted $1-2 \mathrm{~h}$ after sunrise, and in the autumn and winter, falls of the nightly melatonin concentration occured earlier than the rise $(P \leqslant 0.01)$. Nevertheless, duration of the nightly melatonin secretion was longer during the period of short days: 11-12 h (October - February), than under the long-day conditions: 8-10 h (May - August).

The significantly $(\mathrm{P} \leqslant 0.001)$ large differences among the mean nightly concentrations of plasma melatonin were noted in individual ewes during the full reproductive cycle. The annual profiles for each ewe of the mean nightly concentrations of circulating melatonin are shown in Figure 4. In three out of four cases, the highest mean nightly concentrations of melatonin were noted from August to February: $171 \pm 73$ to $329 \pm 187 \mathrm{pg} / \mathrm{ml}(\mathrm{P} \leqslant 0.01 ; \mathrm{P} \leqslant 0.001)$ and also in the individual ewes in April and June: $224 \pm 58$ to $437 \pm 155 \mathrm{pg} / \mathrm{ml}$ $(\mathrm{P} \leqslant 0.01 ; \mathrm{P} \leqslant 0.001)$. The lowest mean concentrations occured from April to the end of July: $123 \pm 40$ to $195 \pm 58 \mathrm{pg} / \mathrm{ml}(\mathrm{P} \leqslant 0.01 ; P \leqslant 0.001)$. In one ewe, the mean nocturnal concentrations of circulating melatonin were maintained at a constant level for most of the year: up to $156 \pm 57 \mathrm{pg} / \mathrm{ml}$, achieving significantly $(\mathrm{P} \leqslant 0.001)$ elevated values in February $(185 \pm 40 \mathrm{pg} / \mathrm{ml})$ and in August $(201 \pm 34 \mathrm{pg} / \mathrm{ml})$. 


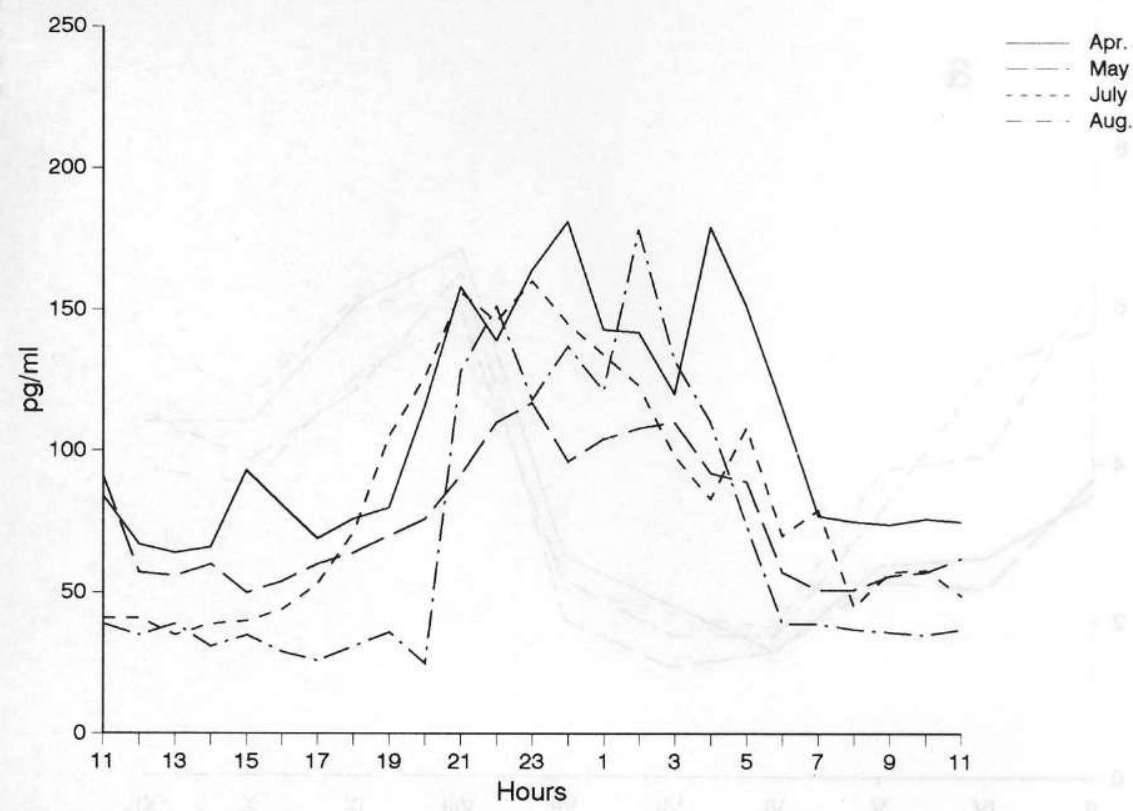

Figure 5. Mean $24 \mathrm{~h}$ patterns of melatonin secretions at for times of the year in rams $(n=4)$ kept under an artificial daylength regime

The changes in duration of melatonin secretion on the average in rams, maintained under the artificial photoperiod during the second year of the experiment, are shown selectively in Figure 5. During the period preceding a change in daylength, duration of the nightly melatonin secretion in rams was reduced to $6 \mathrm{~h}$ in May. Shortening of the daylength from 16 to $8 \mathrm{~h}$ evoked an increase in the duration of melatonin secretion. The longest period of this secretion $-14 \mathrm{~h}$, was observed on the biginning of July, after 6 weeks exposure to short days. A renewed decrease in the duration of melatonin secretion occured after restoration of the natural photoperiod in August. There were no significant differences between the mean nightly concentrations of melatonin in rams maintained either under the natural or artificial photoperiodic conditions. The mean nightly concentrations of plasma melatonin in rams was about $150 \mathrm{pg} / \mathrm{ml}$.

\section{$L H$}

The seasonal changes of the mean $24 \mathrm{~h}$ concentrations of $\mathrm{LH}$ in rams during both years of the experiment are shown in Figure 6. Under the natural daylength conditions, the lowest mean concentrations of LH in blood plasma occured in rams during the period of the longest day, from June to the end of July: $1.7 \pm 0.2$ and $2.4 \pm 0.3 \mathrm{ng} / \mathrm{ml}(\mathrm{P} \leqslant 0.001)$, respectively. A significant increase in the mean 


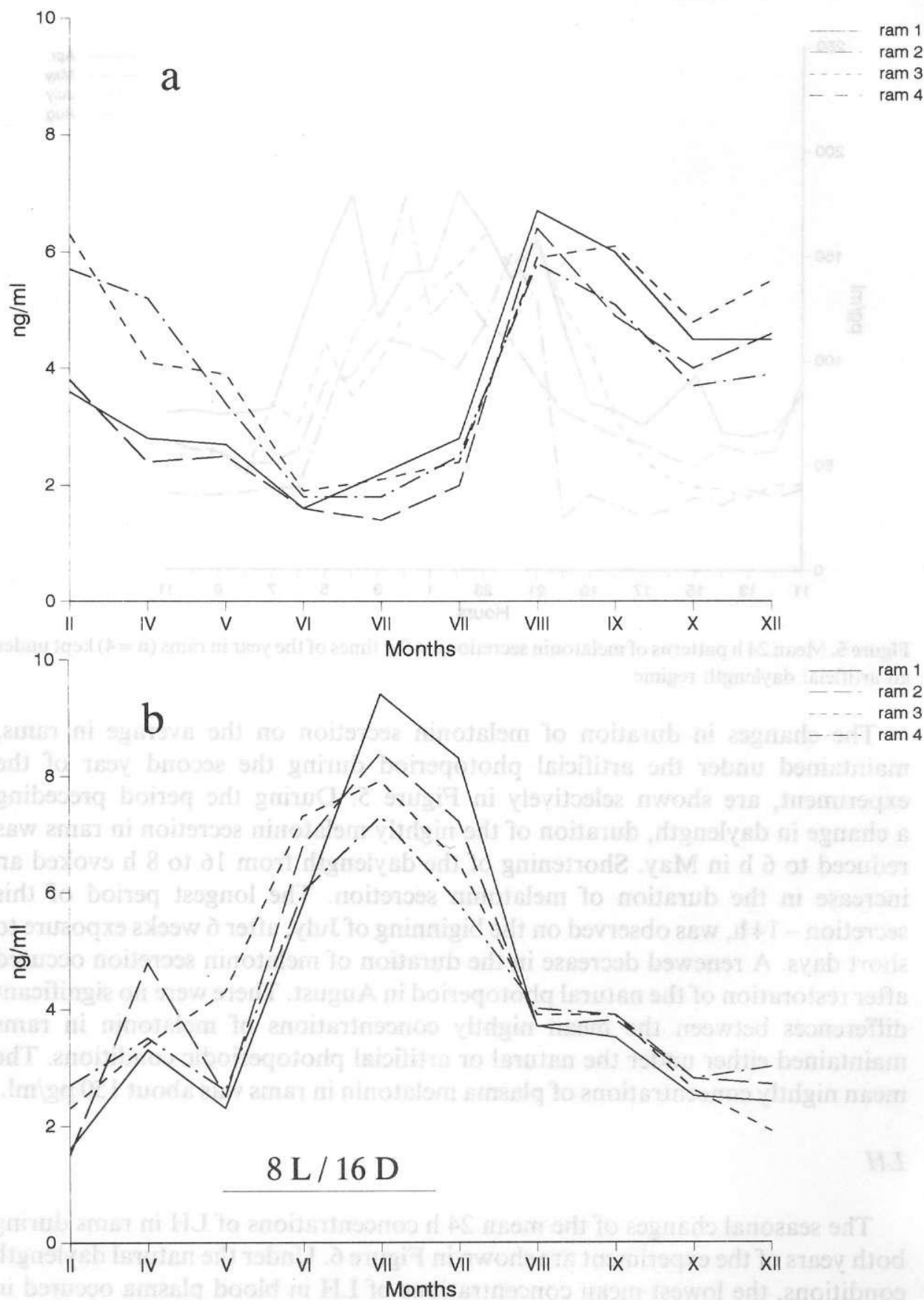

Figure 6. Patterns of the LH concentrations in rams $(n=4)$ under the natural (a) and artificial (b) daylength regimes 
LH concentrations to $6.2 \pm 0.4 \mathrm{ng} / \mathrm{ml}(\mathrm{P} \leqslant 0.001)$, was noted in August. After that, a gradual decrease of $\mathrm{LH}$ was observed until the period of sexual quiescence in February of the following year. Shortening of daylength during the second year of the experiment evoked a significant increase in the mean $\mathrm{LH}$ concentration to $6.5 \pm 0.7 \mathrm{ng} / \mathrm{ml}(\mathrm{P} \leqslant 0.001)$ after 3 weeks, about 9 weeks earlier than under natural photoperiodic conditions. The highest concentrations of circulating $\mathrm{LH}$ were noted at the beginning of July, just after 6 weeks of short days: $8.2 \pm 0.9 \mathrm{ng} / \mathrm{ml}$.

\section{Testosterone}

The testosterone concentrations in blood plasma of rams under the natural photoperiod were low during the reproducing resting period (Figure 7). The significantly high levels of testosterone occured from August until December, with the highest mean concentration in October: $4.6 \pm 0.7 \mathrm{ng} / \mathrm{ml}(\mathrm{P} \leqslant 0.001)$. Under the influence of the shortened daylength during the second year, concentrations of testosterone in blood plasma started to increase at the beginning of July and achieved the highest level in August: $5.2 \pm 0.9 \mathrm{ng} / \mathrm{ml}$ $(\mathrm{P} \leqslant 0.001)$. In October, the level of circulating plasma testosterone in rams was already lower than at the corresponding time in the first year: $2.2 \pm 0.3 \mathrm{ng} / \mathrm{ml} \mathrm{vs}$ $4.6 \pm 0.7 \mathrm{ng} / \mathrm{ml}(P \leqslant 0.001)$.

\section{DISCUSSION}

This local type of Polish sheep, tested in our study, is characterized by a strong sexual behaviour during the autumn months. As we demonstrated in rams, the highest gonadal activity expressed by an increase in the concentration of circulating testosterone was observed from September to December. This was preceded by an increase in LH secretion in August after the summer solstice. During this time, duration of the nocturnal melatonin secretion in the ewes and rams increased. The mean nightly concentrations of circulating melatonin also increased with increasing duration of the dark phase. This latter feature of melatonin secretion was less pronounced in rams than ewes, and may reflect a link between melatonin secretion and ovarian steroid production in females. It may also reflect altered clearance rates for melatonin from the circulation. Since the transition from anoestrus to the breeding season in sheep maintained in the natural photoperiodic conditions does not require a decrease in daylength and appears to be generated by an endogenous process (Robinson and Karsch, 1988; Karsch et al.,1989), our results confirm earlier studies suggesting that seasonal changes in melatonin secretion is one of the factors modulating the breeding activity in this species (Rollag et al.,1978; Arendt et al.,1981, 1983). 

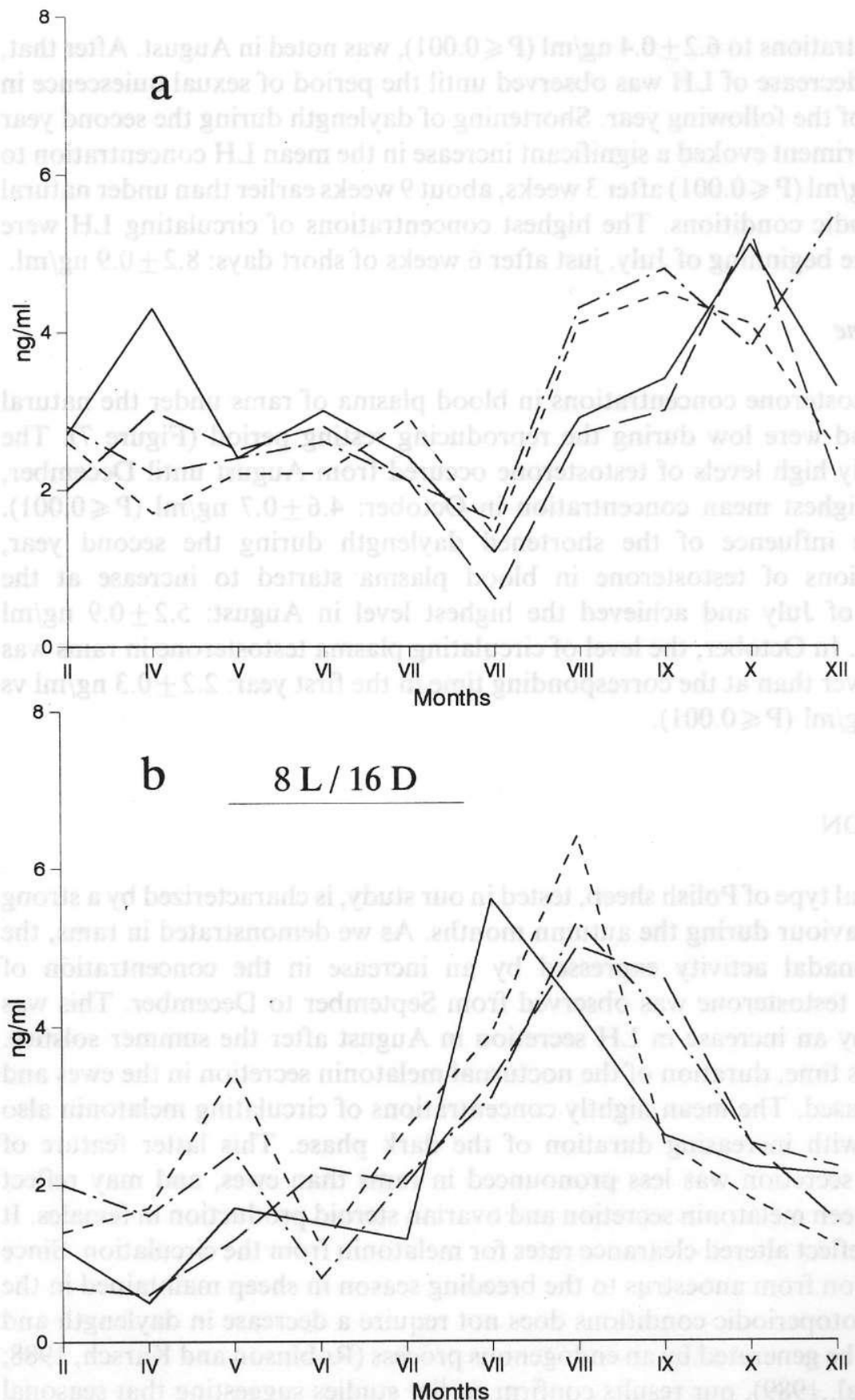

Figure 7. Patterns of the testosterone concentrations in rams $(n=4)$ under the natural (a) and artificial (b) daylength regimes 
The use of melatonin micro-implants positioned in different areas of the ewe brain has revealed that melatonin stimulates neuroendocrine reproductive activity only when the implants are placed in the mediobasal hypothalamus $(\mathrm{MBH})$, but the implants are ineffective when placed in the preoptic area (POA), the dorsolateral hypothalamus or the anterior hypothalamus (Malpaux et al.,1993). Similarly, in rams, melatonin micro-implants stimulate the reproductive axis when placed in the MBH, but not in the POA (Lincoln and Maeda, 1992a,b). These studies suggest, that the MBH is a critical site reached by melatonin, involved in the photoperiodic control of gonadotropin secretion in sheep. This could be through an effect of melatonin on catecholamines located in or close to the MBH (Rassmussens, 1991). Chomicka et al. (1994), showed that increase in the secretion of GnRH from the MBH during late anoestrus is accompanied by a decrease of dopamine release, the main inhibitor of $\mathrm{GnRH}$ in this area (Meycr and Goodman, 1985). Based on these findings, we suppose, that the enhancement of melatonin secretion in ewes, observed in our study during the period of shortening daylenght, may reduce the activity of this inhibitory dopaminergic system in the $\mathrm{MBH}$ and stimulate an increase in the sexual behaviour of sheep at this time.

Shortening of daylength during the second year of our experiment, advanced the reproductive activity of rams by about $6-9$ wecks by comparison with the same rams kept under natural daylength conditions. However, the period of high gonadal activity of rams was shorter during the artificial photoperiod of the second year, than under the natural photoperiod in year 1 . Since the decreasing autumnal daylength and increasing duration of nocturnal secretion of melatonin, is utilized to delay the development of refractoriness and thus maintain the breeding season of normal duration (Malpaux et al., 1988a), a decrease in the duration of melatonin secretion following restoration of the natural daylength in August, could be a factor in our study inhibiting sexual activity of rams during the second year of the experiment. Based on the seasonal changes in melatonin secretion (in the duration and in the mean nightly concentration in plasma), our results strengthen the hypothesis relating to the important role of melatonin in sustaining the genetically encoded length of the breading season (Malpaux and Karsch, 1990). Nevertheless, the mechanism by which melatonin influences the hypothalamic-pituitary-gonadal axis is still unknown.

\section{ACKNOWLEDGEMENTS}

We wish to thank Dr $\Lambda$. Foldes (CSIRO, Australia) for the antiserum against melatonin. This work was supported in part by a grant No 559179203 from the Polish Scientific Research Committee. 


\section{REFERENCES}

Almeida O.F.X., Lincoln G.A.,1984. Reproductive refractoriness in rams and accompanying changes in the pattern of melatonin and prolactin secretion. Biol. Reprod. 30, 143-158

Arcndt J., Symons A.M., Laud C.A., 1981. Pincal function in the sheep: evidence for a possible mechanism medialing seasonal reproductive activity. Experientia 37, 584-589

Arendt J., Symons A.M., Laud C.A., Pryde S.J., 1983. Melatonin can induce early onset of the breeding season in ewes. J. Endocrinol. 97, 395-400

Barrell G.K., Moenter S.M., Caraty A., Karsch F.J., 1992. Scasonal changes in gonadotropinreleasing hormone secretion in the ewe. Biol. Reprod. 46, 1130-1135

Bittman E.L., Karsch F.J.. 1984. Nightly duration of pineal melatonin secretion determines the reproductive respons in inhibitory daylength in the ewc. Biol. Reprod. 30, 585-593

Bittman E.L., Karsch F.J., Hopkins J.W., 1983a. Role of the pincal gland in the ovine photoperiodism; regulation of seasonal breeding and negative fecdback effects of estradiol upon luteinizing hormone secretion. Endocrinology 113, 329-336

Bittman E.L., Dempsey R.J., Karsch F.J., 1983b. Pineal melatonin secretion drives the reproductive response to daylength in the ewe. Endocrinology 113, 2276-2283

Chomicka L.K., Gajewska A., Przekop F., 1994. Release of luteinizing hormone-releasing hormone (LHRH) and dopamine (DA) by the nucleus infundibularis/median eminence (NI/ME) during seasonal anocstrus in ewcs. Neuroendocrinol. 67, Abstract P3.20, p. 67

Clarke I.J., Cummins J.T., 1982. The temporal relationship between gonadotropin-releasing hormone and luteinizing hormone secretion in ovariectomized ewes. Endocrinology 111, 1737-1739

Ducker M.J., Thwaites C.J., Bowman J.C., 1970. Photoperiodism in the ewe. 2. The effects of various patterns of decreasing daylength on the onset of oestrus in Clun Forest ewes. Anim. Prod. 12, $115-123$

Fraser S., Cowen P., Franklin M., Franey C., Arendt J., 1983. Direct radioimmunoassay for mclatonin plasma. Clin. Chcm. 29, 396-397

Karsch F.J., Bittman E.L., Foster D.I., Goodman R.L., Legan S.J., Robinson J.E., 1984. Neuroendocrine basis for seasonal reproduction. Rec. Prog. Horm. Res. 40, 185-225

Karsch F.J., Bittman E.L., Robinson J.E., Yellon S.M., Wayne N.L., Olster D.H., Kaynard A.H., 1986. Melatonin and photorefractoriness: loss of response to the melatonin signal leads to seasonal reproductive transitions in the ewe. Biol. Reprod. 34, 265-274

Karsch F.J., Robinson J.E., Woodfill C.J.I., Brown M.B., 1989. Circannual cycles of luteinizing hormone and prolactin secretion in ewes during prolonged exposure to a fixed photoperiod; evidence for an endogenous reproductive rhythm. Biol. Reprod. 41, 1034-1046

Lincoln G.A., Meada K.I., 1992a. Reproductive effects of placing micro-implants of melatonin in the mediobasal hypothalamus and preoptic arca in rams. J. Endocrinol. 132, 201- 215

Lincoln G.A., Meada K.I., 1992b. Effects of placing micro-implants of mclatonin in the mediobasal hypothalamus and preoptic area on the secretion of prolactin and $\beta$-endorphin in rams. J. Endocrinol. 134, 437-448

Lincoln G.A., Pett M.J., Cunningham R.A., 1977. Seasonal and circadian changes in the episodic rclease of follicle-stimulating hormone, luteinizing hormone and testosterone in the ram. J. Endocrinol. 72, 337-349

Malpaux B., Karsch F.J.,1990. A role for short days in sustaining seasonal reproductive activity in the ewe. J. Reprod. Fertil. 90, 555-562

Malpaux B., Robinson J.E., Brown M.B., Karsch F.J., 1987. Reproductive refractoriness of the ewe to inductive photoperiod is not caused by inappropriate secretion of melatonin. Biol. Reprod. $36,1333-1341$ 
Malpaux B., Robinson J.E., Brown M.B., Karsch F.J., 1988a. Importance of changing photoperiod and melatonin secretory pattern in determining the length of the breeding season in the Suffolk ewe. J. Reprod. Fertil. 83, 461-470

Malpaux B., Moenter S.M., Wayne N.L., Woodfill C.J.I., Karsch F.J., 1988b. Reproductive refractoriness of the ewe to inhibitory photoperiod is not caused by alteration of the circadian secretion of melatonin. Neuroendocrinology $48,264-270$

Malpaux B., Daveau A., Maurice F., Gayrard V., Thiery J-C., 1993. Short-day effects of melatonin on lutcinizing hormone sccretion in the ewc: evidence for central sitcs of action in the mediobasal hypothalamus. Biol. Reprod. 48, 752-760

Maxwell C.A., Rintoul A.J., Foldes A., Downing J.A., Scaramuzzi R.J., Cantor N.B., 1989. Seasonal modifications of ovine pineal functions. 2.Steroidal effects on melatonin and prolactin profiles. Neurocndocrinology 50, 274-279

Meyer S.L., Goodman R.L., 1985. Neurotransmitters involved in mediating the steroid dependent suppression of pulsatile luteinizing hormone secretion in anestrous ewes; effects of receptor antagonists. Endocrinology 116, 2054-2061

Moore R.J., Klein D.C., 1974. Visual pathways and the central neural control of a circadian rhythm in pineal serotonin $\mathrm{N}$-acetyltransferase activity. Brain Res. 71, 17-33

Nett T.M., Niswender G.D., 1982. Influens of enxogenous melatonin on scasonality of reproduction in sheep. Theriogenology 17,645-651

Rassmussens D.D., 1991. The interaction between mediobasohypothalamic dopaminergic and endorphinergic neuronal systems as a key regulator of reproduction: an hypothesis. J. Endocrinol. Invest. 14, 323-352

Robinson J.E., Karsch F.J., 1988. Timing the breeding season of the ewe: what is the role of daylength? Reprod. Nutr. Develop. 28, 365-374

Rollag M.D., O'Callaghan P.L., Niswender G.D., 1978. Serum melatonin concentrations during different stages of the annual reproductive cycle in ewes. Biol. Reprod. 18, 279-285

Stupnicki R., Madej A., 1976. Radioimmunoassay of LH in blood plasma of farm animais. Endokrinologie 68, 6-13.

Stupnicki R., 1985. Radioimmunoassay of testosterone. In: F.Kokot, R.Stupnicki (Editors), Radioimmunoassay and radiocompetition methods applied in clinics. PZWL. Warszawa, pp. 273-281.

Theodorsson-Norheim E., 1986. Kruskal-Wallis test: BASIC computer program to prform nonparametric one-way analysis of variance and multiple comparisions of ranks of several independent samples. Comp. Meth. Prog. Biomed. 23, 57-62

Wayne N.L., Malpaux B., Karsch F.J., 1988. How does melatonin code for day length in the ewe: duration of nocturnal melatonin release or coincidence of melatonin with a light-entrained sensitive period. Biol. Reprod. 39, 66-75

\section{STRESZCZENIE}

\section{Sezonowe zmiany melatoniny w zależności od cyklu reprodukcyjnego owiec}

Określono sczonowe zmiany w sekrecji melatoniny u maciorek i tryków utrzymywanych przez cały rok w naturalnych warunkach oświetleniowych oraz u tryków pod wpływem sztucznych zmian długości dnia w drugim roku badań. Jednocześnie, u tryków oznaczono w osoczu stężenia hormonu luteotropowego i testosteronu. 
W ciągu dnia stężenie melatoniny w osoczu owiec wynosiło od $41 \pm 7 \mathrm{do} 112 \pm 13 \mathrm{pg} / \mathrm{ml}$, a istotny wzrost ponad wartości dzienne następował podczas pierwszej godziny po zachodzie słońca. Czas trwania nocnej sckrecji mclatoniny był dłuższy w warunkach dnia krótkicgo: 11-12 godzin, niż w warunkach dnia długiego: 8-10 godzin. Stwierdzono również, że różnice pomiędzy średnimi nocnymi stężeniami melatoniny we krwi były u poszczególnych maciorek wysoce istotne $(P \leqslant 0,001)$ w okresie pełnego cyklu reprodukcyjnego. Najwyższe średnie nocne stężenia stwierdzono w okresie skracającego się dnia, od sicrpnia do lutego: $171 \pm 73-329 \pm 187 \mathrm{pg} / \mathrm{ml}$.

W naturalnych warunkach świetlnych, średnie dobowe stężenia LH i testosteronu w osoczu tryków utrzymywały się na niskich poziomach przez cały okres obniżonej aktywności płciowej, a najwyższe koncentracje stwierdzono odpowicdnio w sicrpniu: $6,2 \pm 0,4 \mathrm{ng} / \mathrm{ml} \mathrm{i} \mathrm{w}$ październiku $4,6 \pm 0,7 \mathrm{ng} / \mathrm{ml}$.

Skrócenie dlugości dnia z 16 do 8 godzin w maju spowodowało wydłużenie siẹ okresu nocnej sckrecji mclatoniny u tryków z 6 do 14 godzin. Nasilenie się funkcji rozrodczych wystąpiło o 6 do 9 tygodni weześniej niż w pierwszym roku badań, a szczyt sekrecji LH i testosteronu stwierdzono odpowiednio na począlku lipca: $8,2 \pm 0,9 \mathrm{ng} / \mathrm{ml} \mathrm{i}$ w sierpniu: $5,2 \pm 0,9 \mathrm{ng} / \mathrm{ml}$. Okres aktywności płciowej tryków w sztucznych warunkach świetlnych podczas drugiego roku badań był jednak krótszy niż w warunkach naturalnej długości dnia w pierwszym roku. 